\title{
Optimalisasi Pemanfaatan Kincir Air Terapung Untuk Mensuplai Kebutuhan Air Sawah Tadah Hujan Di Nagari Rajo Dani Tanah Datar
}

\author{
Hendri Nurdin ${ }^{*}$ ) Hasanuddin, Irzal, Waskito \\ Jurusan Teknik Mesin - Fakultas Teknik - Universitas Negeri Padang \\ *)Corresponding author, $\equiv$ hens2tm@ft.unp.ac.id
}

Revisi 10/07/2019;

Diterima 15/08/2019;

Publish $05 / 09 / 2019$

Kata kunci: Sawah tadah hujan, air, kincir air terapung, penerapan teknologi

\begin{abstract}
Abstrak
Kebutuhan air yang banyak seringkali menimbulkan permasalahan bagi manusia karena merupakan kebutuhan hidup. Air juga tidak terlepas dengan sektor pertanian, terutama tanaman padi sebagai sumber pokok pangan masyarakat Indonesia. Daerah Kabupaten Tanah Datar terkenal dengan hasil pertaniannya berupa padi. Lumbung padi di daerah di daerah ini adalah Nagari Padang Ganting yang terletak di dataran tinggi. Daerah ini memiliki lahan pertanian persawahan tadah hujan yang penghidupan masyarakatnya sebahagian besar adalah sebagai petani sebagai penghasilan utamanya. Berdasarkan hasil survei yang dilakukan pada masyarakat kelompok tani Makam Tuan Kadhi dan Tangah Koto di Nagari Rajo Dani, diperoleh informasi tentang permasalahan kekurangan air untuk persawahan. Dari ungkapan tersebut sehingga dipilih solusi untuk menerapkan kincir air terapung yang dapat menggerakkan pompa untuk mensuplai kebutuhan air persawahan. Dengan pemanfaatan air sungai sebagai potensi sumber energi dalam menggerakkan kincir air sebagai tenaga penggerak pompa dinilai tepat untuk mengatasi permasalahan petani. Hasil dari kegiatan ini berupa penerapan rancang bangun kincir air terapung bagi kelompok masyarakat tani Nagari Rajo Dani Padang Ganting untuk mengatasi kebutuhan persawahan. Kinerja kincir air terapung yang diterapkan memiliki efisiensi sebesar 85\% sehingga kapasitas kerja pompa dalam mensuplai air sebesar 5,68 $\mathrm{m}^{3} /$ hari. Dampak nyata bagi masyarakat dirasakan dengan meningkatkan produktifitas panen dan kesejahteraan yang lebih baik.
\end{abstract}

\section{PENDAHULUAN}

Kabupaten Tanah Datar di Sumatera Barat dengan ibu kotanya Batu Sangkar terkenal dengan hasil pertaniannya berupa padi. Salah satu lumbung padi di daerah Batu Sangkar adalah Nagari Padang Ganting. Nagari Padang Ganting merupakan tanah dataran yang membujur dari barat ke timur dengan luas areal $33 \mathrm{~km}^{2}$ atau $3.833 \mathrm{ha}$, dengan panjang $11 \mathrm{~km}$ dan lebar $3 \mathrm{~km}$. 
Terletak di ketinggian 700 meter di atas permukaan laut (Datar, 2012). Sebagian besar luas wilayahnya digunakan untuk sawah dan perkebunan dengan luas daerah 3.081 ha yang terdiri dari sawah irigasi 260 ha dan sawah tadah hujan 92 ha. Nagari Padang Ganting memiliki empat jorong. Yaitu Jorong Koto Gadang, Rajo Dani, Koto Alam dan Rajo Dani Hilir. Jika dilihat bentuk kenagarian ini dari tempat yang tinggi, berbentuk sebuah kuali karena dikelilingi oleh bukitbukit sekaligus menjadi batas-batas dengan daerah lain disekitarnya. Keadaan tanah di kenagarian ini bolehlah dikatakan masuk daerah subur, berkat adanya beberapa batang air (sungai) yang mengalir di sini, diantaranya batang selo, batang bandar, batang pagie. Di daerah bukit-bukit tersebut terdapat lahan pertanian masyarakat yang merupakan penghasilan utamanya. Umumnya lahan pertaniannya banyak yang tadah hujan. Banyaknya lahan yang tadah hujan membuat pemamfaatan lahan tersebut kurang efektif dan efisien, karena kekurangan air. Padahal air tidak terlepas dengan sektor pertanian, terutama tanaman padi sebagai sumber pokok pangan masyarakat Indonesia.Air merupakan kebutuhan yang sangat penting bagi manusia, hewan dan tumbuh-tumbuhan. Kebutuhan air yang cukup banyak seringkali menimbulkan permasalahan bagi manusia, khususnya bagi masyarakat yang tinggal jauh dari sumber air atau berada di di atas sumber air.

Daerah yang memiliki areal persawahan yang cukup luas baik sawah irigasi maupun sawah tadah hujan yaitu Jorong Rajo Dani yang berada pada dataran tinggi Daerah ini berada sejauh $120 \mathrm{~km}$ dari kota Padang dengan waktu tempuhnya untuk mencapai lokasi \pm 3 jam. Penghidupan masyarakat daerah ini sebahagian besar adalah sebagai petani yang rata-rata memiliki petak persawahan seluas 1 sampai 2 ha. Lahan pertanian tadah hujan hanya bisa bercocok tanam 1 kali dalam setahun, namun sering gagal panen juga dikarenakan curah hujan yang tidak tepat. Sementara lahan yang dapat irigasi dapat bercocok tanam 3 kali dalam setahun. Penanaman padi di persawahan dengan menggunakan sistem pengairan irigasi konvensional, sangat menguntungkan masyarakat dari segi produksi (Namara et al., 2011). Sementara sistem irigasi sendiri terdiri dari dua macam, yaitu lift irrigation dan flow irrigation. Lift irrigation (irigasi pompa), merupakan sistem penyaluran air dari lokasi yang rendah ke lokasi yang tinggi dengan cara manual maupun mekanis. Sedangkan flow irrigation (irigasi aliran), merupakan penyaluran air yang dialirkan secara gravitasi dari sumber air ke tempat lahan pertanian.

Survei yang dilakukan pada Jorong Rajo Dani dengan berkomunikasi bersama masyarakat para petani diperoleh berbagai informasi permasalahan yang disampaikan. Di Jorong Rajo Dani terdapat beberapa kelompok tani masyarakat diantaranya kelompok tani Tangah Koto dan kelompok tani Makam Tuan Kadhi. Masyarakat di Jorong ini ada juga yang tidak ikut sebagai kelompok tani tetapi tanah pertaniannya dikerjakan orang lain. Kelompok tani Tangah Koto yang diketuai Bapak Martis Wandri yang sudah lama berdiri dan beranggotakan 15 orang masyarakat tani. Kelompok tani lainnya yaitu Makam Tuan Kadhi yang diketuai oleh Ibu Nurmi yang baru mendirikan kelompok tani ini bersama anggotanya \pm 3 tahun dan memiliki anggota 12 orang masyarakat tani. Dari survei ini, masyarakat tani mengeluhkan kekurangan air untuk petak persawahan mereka. Apalagi ketika musim kemarau datang permasalahan ini terus membayangi masyarakat dan pembiayaan operasional pengerjaan untuk persawahan menjadi lebih tinggi. Masyarakat petani menjadi gusar akan sawahnya sehingga bagi masyarakat yang punya selalu melakukan pemompaan air dari sungai. Dimana sungai ini merupakan potensi daerah ini yang letaknya disepanjang areal persawahan mereka (Gambar 1) yang berada di dataran rendah yang pemanfaatannya hanya sebagian saja oleh masyarakat. Bila diperhatikan bahwa sungai ini juga menjadi sumber air irigasi namun hanya yang berada disekitar sungai yang memperoleh. 


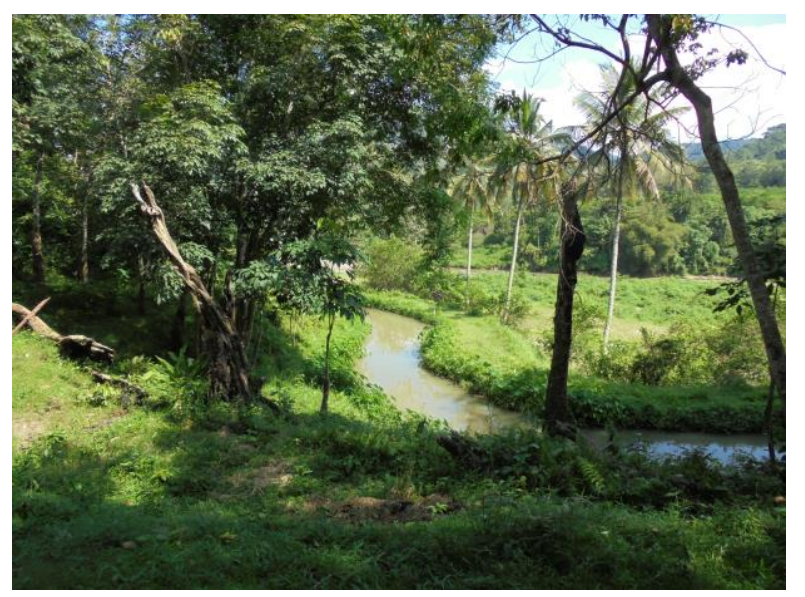

Gambar 1. Batang Air (Sungai) sebagai Sumber Potensi Energi

Namun dikarenakan sungai tersebut berada pada dataran rendah sehingga petak persawahan yang berada di dataran tinggi akan kesulitan air, sehingga air persawahan hanya diharapkan dari air hujan atau menyewa pompa untuk mensuplai air ke sawah. Untuk memompa dan menaikkan air dari sumber air (sungai) ke tempat areal persawahan pada dataran tinggi, masyarakat biasanya menggunakan pompa. Penggunaan pompa air ini masih mengalami kesulitan, antara lain tidak tersedianya sumber tenaga listrik atau sulitnya mendapatkan bahan bakar dan mahalnya biaya operasional pompa. Bagi petani yang kurang mampu biasanya mereka menyewa pompa orang lain dengan biaya Rp. 30.000/jam. Dalam sekali penggunaan penyewaan pompa air untuk mengairi satu petak persawahan ( \pm 1 hektar) dibutuhkan waktu selama 5 jam, sehingga masyarakat petani harus mengeluarkan biaya tambahan Rp. 150.000,-. Satu kali periode panen sawah pada musim kemarau dibutuhkan sebanyak 6 kali menyewa pompa air untuk satu petak persawahan. Sehingga pembiayaan modal petani untuk menghasilkan panen padi yang baik semakin bertambah besar dan kondisi ini menjadikan pendapatan para petani menjadi berkurang. Belum lagi ancaman yang masih dapat dimungkinkan untuk gagal panen. Bagi para petani yang tidak mempunyai modal pembiayaan, hal ini akan menjadikan sesuatu yang dapat berdampak langsung. Karena Cuma mengharapkan air dari pompa sehingga banyak petani tersebut gagal panen.

Berdasarkan ungkapan dari masyarakat petani di kenagarian Jorong Rajo Dani dengan masalah yang dihadapi oleh masyarakat petani menjadikan timbulnya ide gagasan kegiatan ini untuk menyelesaikan permasalahan masyarakat petani sebagai mitra. Informasi ini diperoleh dari masyarakat oleh tim pelaksana ketika melakukan survei ke daerah Jorong Rajo Dani dan melakukan komunikasi langsung dengan masyarakat petani dan pemuka masyarakat yang sangat membutuhkan air persawahan.

Banyak hal yang diungkapkan oleh masyarakat petani sehingga diambil kesimpulan bersama untuk menerapkan sebuah kincir air screw yang dapat menggerakkan pompa untuk mensuplai kebutuhan air persawahan. Pemanfaatan energi air banyak dilakukan dengan menggunakan kincir air (roda air) atau turbin air yang memanfaatkan adanya suatu air terjun atau aliran sungai (Sule, 2015). Kincir air merupakan teknologi sederhana yang cukup digerakkan dengan aliran air yang tidak terlalu besar, tetapi dapat memberikan daya yang 
cukup besar (Yusri, Zamri, \& Asmed, 2012). Penerapan kincir air sebagai penggerak pompa untuk mensuplai kebutuhan air persawahan menjadi solusi yang dipilih (Nurdin, Hasanuddin, \& Irzal, 2017). Rancang bangun kincir air penggerak pompa berupa model alat teknologi tepat guna yang dapat diterapkan di masyarakat (Ismanto, Trinofrandesta, \& Hamid, 2015). Dengan adanya sungai sebagai potensi sumber energi dan sumber air, sehingga kincir air sebagai tenaga penggerak pompa yang akan direalisasikan, dinilai cukup tepat untuk mengatasi permasalahan peralatan atau proses produksi pertanian. Peluang kerja sama sangat dimungkinkan dengan para petani sebagai mitra pengabdian, karena begitu besar harapan para petani terhadap alat teknologi tepat guna yang akan diterapkan tersebut karena alat mempunyai beberapa keuntungan jika dibandingkan dengan jenis alat yang lain, yaitu tidak membutuhkan energi listrik atau bahan bakar, air bisa dinaikan ketempat yang cukup tiggi (sama dengan kemampuan pompa), tidak mudah korosi, ukuran diameternya tidak terlalu besar dan tidak membutuhkan tobek (bendungan) yang panjang biaya pembuatan dan pemeliharaannya relatif murah serta pembuatannnya cukup mudah dan kami rasa bisa diproduksi secara masal.

Dengan kincir air yang akan direalisasikan nantinya, masyarakat petani sangat mengharapkan permasalahan yang ada dapat terselesaikan. Harapan dari program ipteks yang nantinya akan diterapkan menjadikan salah satu upaya dalam mengatasi masalah yang ada dimasyarakat Jorong Rajo Dani Padang Ganting. Dipilihnya daerah ini dengan harapan bahwa setelah pelaksanaan kegiatan nantinya masyarakat dapat menikmati suplai air untuk kebutuhan air persawahan melalui kincir air dan juga pendapatan para petani dapat lebih meningkat.

\section{METODE PELAKSANAAN}

Dalam melaksanakan kegiatan yang diterapkan dalam mengatasi permasalahan yang terjadi pada Kelompok tani Tangah Koto dan Kelompok tani Makam Tuan Kadhi yang berada di Jorong Rajo Dani Nagari Padang Ganting. Metode pendekatan ditawarkan kepada kelompok tani sebagai mitra program kegiatan pengabdian masyarakat. Solusi yang ditawarkan bersifat pemecahan permasalahan yang dialami oleh masyarakat petani, sehingga dampak dari pelaksanaan kegiatan ini dapat dirasakan menyeluruh. Kegiatan ini direncanakan dalam bentuk rancang bangun kincir air terapung, rekayasa pompa torak, dan penyuluhan dan pelatihan kepada masyarakat kelompok tani. Tahapan kegiatan ini dimulai dengan persiapan dan perencanaan, pelaksanaan, pamantauan dan evaluasi.

Pada tahapan persiapan dan perencanaan dilakukan koordinasi dengan pihak Lembaga Penelitian dan Pengabdian pada Masyarakat (LP2M) Universitas Negeri Padang dengan lembaga atau pihak terkait (perangkat nagari Rajo Dani Padang Ganting, kelompok tani, terutama untuk menentukan lokasi kegiatan dan jadwal pelaksanaan kegiatan. Di pihak tim pelaksana kegiatan, dalam tahap ini dilakukan persiapan bahan dan peralatan yang diperlukan, pendistribusian tugas ke masing-masing anggota tim dan persiapan ke lapangan serta pembuatan kisi-kisi evaluasi yang akan dipergunakan pada saat pemantauan kegiatan. Pemantauan, evaluasi, dan pembinaan dilakukan dengan jangka waktu yang telah ditentukan.

Metode penerapan ipteks yang dilakukan pada kegiatan ini berupa perencanaan (Gambar 2) dan pembuatan kincir air terapung sebagai penggerak pompa. Kincir air terapung ini digerakkan dengan memanfaatkan aliran air sungai yang berada di daerah Jorong Rajo Dani. Putaran kincir direduksi menggunakan puli dan sabuk sehingga dapat menggerakkan putaran pompa yang dipasangkan pada bagian belakang kincir. Pompa air yang memiliki head 30 meter 
dapat menghisap dan memompakan air yang berada jauh dari sungai dan pada dataran yang lebih tinggi.

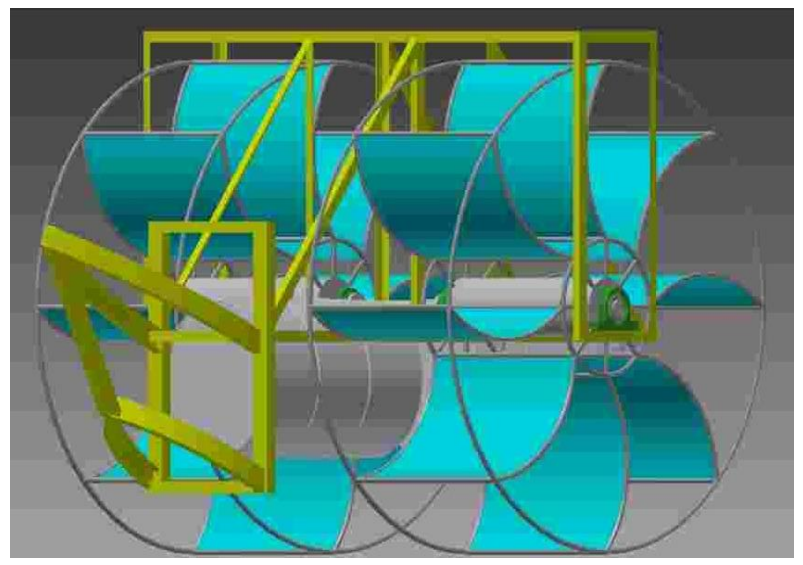

Gambar 2. Rancangan Kincir Air Terapung

Pada prinsipnya evaluasi dilaksanakan selama pelaksanaan kegiatan, baik di awal kegiatan, pada saat kegiatan berlangsung maupun setelah semua kegiatan selesai dilakukan (evaluasi produk). Dengan evaluasi yang dilakukan apabila selama kegiatan terjadi kekurang-sesuaian dengan yang telah ditetapkan bersama mitra dapat dilakukan pembenahan sesuai dengan jenis kesalahan dan ketidak-sesuaian tersebut. Sedangkan evaluasi produk dimaksudkan untuk mengetahui ketercapaian program yang telah dirumuskan sejak awal kegiatan, dan yang lebih penting dapat diketahui tanggapan khlayak sasaran dan instansi/lembaga terkait yang terlibat dalam kegiatan tentang dampak pelaksanaan kegiatan ipkteks bagi masyarakat.

Rancangan evaluasi berupa ketepatan pelaksanaan kegiatan dengan jadwal, koordinasi dan mekanisme kerja dalam tim pelaksana, dengan aparat atau instansi terkait. Motivasi dan partisipasi serta Situasi dan kondisi pada masyarakat khususnya Kelompok Tani Koto Tangah dan kelompok Tani Makam Tuan Kadhi selama kegiatan berlangsung sehingga menumbuhkan interaksi tim dengan masyarakat. Evaluasi terhadap proses pembuatan kincir air screw terapung.

Indikator capaian program kegiatan yang dilakukan berupa kapasitas kerja kincir air screw terapung untuk menggerakkan pompa yang dapat menaikkan air ke persawahan yang berada pada dataran tinggi sehingga menunjukkan kinerja efektifitas yang maksimal. Ketermanfaatan sumber energi yang berada di daerah untuk mengatasi permasalahan masyarakat mitra.

Tolak ukur keberhasilan program kegiatan pengabdian pada masyarakat in dengan kriteria berupa terjadinya peningkatan produktifitas hasil panen padi dan suplai air persawahan. Adanya peningkatan pendapatan dan kesejahteraan masyarakat dan berkembangnya pemahaman, wawasan dan penerapan ilmu dan teknologi tepat guna pada masyarakat mitra.

\section{HASIL DAN PEMBAHASAN}

Kegiatan Ipteks bagi Masyarakat ini dilakukan beberapa tahap. Setiap tahapan yang direncanakan saling terkait dengan tahapan berikutnya. Perencanaan tahapan kegiatan ini 
berdasarkan pekerjaan yang sudah direncanakan. Dari gambaran kegiatan yang diterapkan ke kelompok tani sebagai masyarakat mitra pengabdian masyarakat diperoleh berbagai kesepakatan dan komitmen bersama sebagai wujud realisasi program yang difasilitasi oleh pihak pemuka masyarakat dan perangkat nagari terkait di Nagari Rajo Dani Padang Ganting. Penerapan Ipteks yang dilaksanakan yaitu Rancang Bangun alat berupa kincir air terapung untuk menggerakkan pompa. Kincir air poros vertikal dianggap menyederhanakan sistem transmisi di mana energi mekanik dapat langsung terhubung ke peralatan yang diinginkan ke perangkat seperti mesin penggilingan, pompa, dan sebagainya (Darmawi, Sipahutar, Bernas, \& Imanuddin, 2013). Rekayasa kincir air terapung ini sebagai pensuplai kebutuhan air persawahan tadah hujan masyarakat di Nagari Rajo Dani Padang Ganting. Air yang disuplai berasal dari sungai yang berada di bawah dari petak-petak persawahan masyarakat. Sistem dan mekanisme konstruksi kincir air yang dibangun menggunakan model penyambungan baut (sistem knok down) sehingga mudah untuk pemasangan di lapangan (Gambar 3).

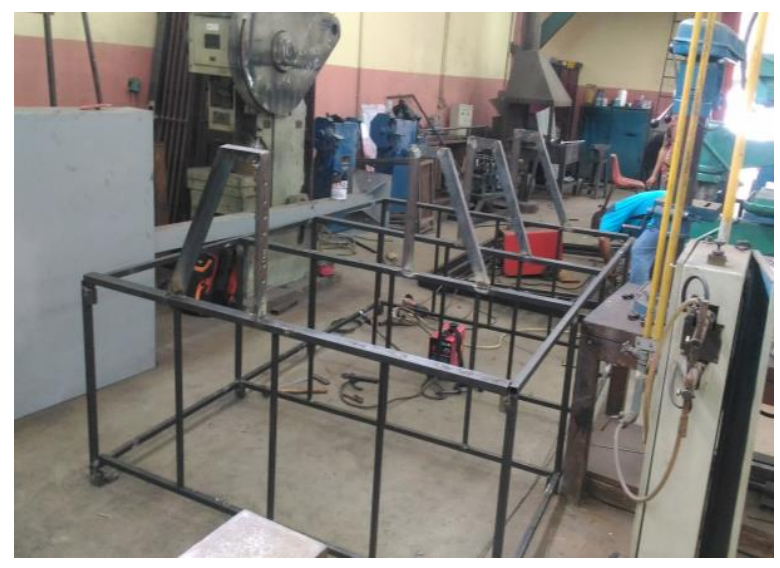

Gambar 3. Konstruksi kincir air

Pekerjaan fabrikasi konstruksi dudukan sudu kincir air (Gambar 4) sebagai dudukan sudu (blade) kincir berukuran diameter 1,8 $\mathrm{m}$ dan lebar 0,8 $\mathrm{m}$. Kincir air memiliki konstruksi sudu (blade) sebanyak 2 buah yang berposisi pada bagian kiri dan kanan. Pada bagian tengah di pasang poros kincir berukuran 2" dengan diselubungi pipa sebesar 6" yang berfungsi untuk menambah beban torsi dan penyeimbang putaran kincir. Sudu kincir diposisikan pada rangka yang dibentuk elips dengan berukuran tinggi $1 \mathrm{~m}$ dan panjang 0,8 $\mathrm{m}$. Dinding sudu dapat berputar pada porosnya sehingga akan menimbulkan kecepatan keliling pada ujung dinding sudu, dengan demikian akan mengakibatkan adanya kecepatan relatif air pada dinding (sudu) (Ismanto et al., 2015). Kerja yang dihasilkan untuk $1 \mathrm{~kg}$ air/detik adalah gaya yang bekerja dikaitkan dengan kecepatan (Streeter, Wylie, \& Bedford, 1985). Jumlah sudu kincir yang dibuat sebanyak 8 buah sudu dan dibuat sama pada bagian lainnya (bagian kiri dan kanan sama jumlah sudunya). Dalam mentransmisikan daya dari putaran kincir ke pompa menggunakan poros dimana perencanaannya dapat dihitung menggunakan beberapa persamaan (Sularso, 2004). 


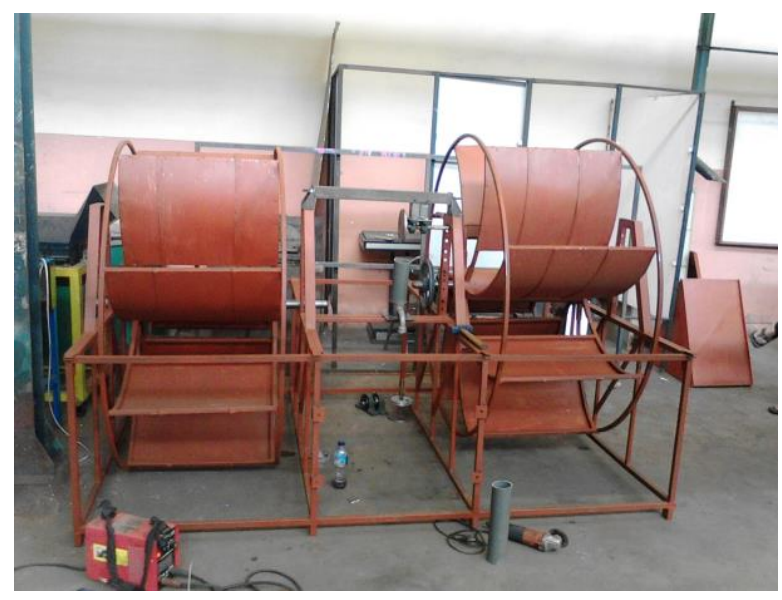

Gambar 4. Konstruksi sudu (blade) kincir

Komponen kelengkapan kincir air terapung, di fabrikasi produksi dengan ukuran panjang 2 $\mathrm{m}$ dan lebar 2,6 m serta tinggi 0,75 m. Pada bagian samping kiri dan kanan dibangun berbentuk kotak persegi sebagai tempat peletakan konstruksi blade (sudu). Pada bagian tengah disediakan sebagai tempat peletakan drum plastik sebanyak 3 buah. Drum palstik yang digunakan berukuran diameter $0,65 \mathrm{~m}$ x 0,95 $\mathrm{m}$ yang berkapasitas 100 liter.

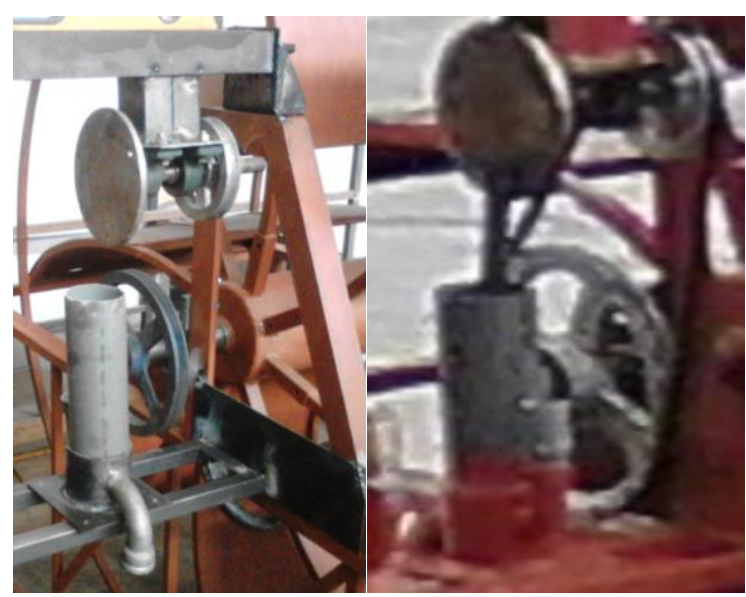

Gambar 5. Konstruksi pompa torak

Setelah set-up komponen konstruksi terselesaikan, maka dilanjutkan dengan rancang bangun pompa torak yang dalam hal ini disesuaikan output putaran yang dihasilkan sudu kincir. Rancang bangun pompa torak untuk memompakan air dari sungai langsung menuju sawah tadah hujan. Pompa torak yang dibuat dapat dioperasionalkan pada putaran rendah (dibawah $20 \mathrm{rpm}$ ), kemudian putaran dinaikkan dengan perbandingan puli dan sabuk sebagai transmisi. Mekanisme pompa torak (Gambar 5) ini disesuaikan dengan putaran kincir air yang memiliki putaran yang rendah. Pompa torak ini disesuaikan dengan kecepatan aliran air sungai secara rata-rata dan debit air yang menggerakkan sudu kincir. Dimensi pompa torak memiliki 
diameter torak $68 \mathrm{~mm}$, panjang langkah torak $150 \mathrm{~mm}$ dan tinggi konstruksi pompa torak 35 cm. Pompa torak ini memiliki 2 buah katup berukuran 1" yaitu katup masuk dan katup keluar berukuran 3/4" yang diposisikan pada bagian ujung silinder. Pompa torak ini dirancang sebanyak 2 buah yang di posisikan pada bagian tengah kincir dan dihubungkan melalui puli dan sabuk pada ujung poros sudu bagian dalam.

Setelah terselesaikannya semua komponen kincir air, maka tahapan selanjutnya berupa pemasangan dan perakitan kincir air di lokasi sungai yang sudah ditentukan dan memiliki debit aliran yang maksimal. Pemasangan dan perakitan kincir air dilakukan tim pelaksana bersama mahasiswa dan masyarakat kelompok mitra. Kendala dan hambatan dalam pelaksanaan pemasangan diminimalisir dengan bentuk kebersamaan dan gotong royong, sehingga waktu kerja pemasangan menjadi lebih singkat.

Selanjutnya tahapan ujicoba kinerja kincir air pada aliran sungai setelah perakitan seluruh komponen terpasang. Pada tahapan ujicoba kinerja kincir air dilakukan tim pelaksana bersama-sama dengan mahasiswa dan masyarakat. Kinerja kincir air sangat memuaskan, namun pompa belum bekerja maksimal dalam mensuplai air ke sawah yang berada pada dataran tinggi. Denga demikian diperlukan perbaikan dari mekanisme pompa torak. Sehingga untuk sementara ditangguhkan penggunaan kincir air.

Dalam melaksanakan perbaikan dibutuhkan diskusi dan waktu untuk menghasilkan kinerja pompa yang maksimal. Analisa kondisi yang terjadi dilapangan menjadi pedoman dalam mensikapi dan merealisasikan perbaikan kinerja pompa. Fokus dan target perbaikan pada mekanisme piston dan penggerak serta transmisi penghubung dari poros kincir ke poros pompa. Dalam perbaikan ini dilakukan penggantian dari beberapa komponen pompa. Finalisasi perbaikan dilakukan setelah mekanisme pompa bekerja normal dan ringan dalam operasionalnya. Uji kinerja perbaikan di labor menunjukkan ketercapaian hasil yang sudah baik dan siap untuk di pasang kembali ke mekanisme kincir air.

Pemasangan pompa torak pada mekanisme kincir air di lokasi sungai Nagari Rajo Dani Padang Ganting dilakukan bersama dengan masyarakat. Keinginan dan keberharapan untuk dapat memanfaatkan kincir air sebagai pensuplai kebutuhan air persawahan menjadi kekuatan bagi tim pelaksana untuk segera menyelesaikannnya. Pada situasi ini tim pelaksana menyampaikan beberapa hal sebagai bentuk penyuluhan dan pelatihan terhadap masyarakat mitra. Penyelesaian akhir dari pemasangan yang dilakukan yaitu menguji dan mengukur untuk mendapatkan kinerja pompa secara maksimal. Sebelumnya dipersiapkan beberapa hal diantaranya memposisikan kincir air pada daerah aliran air yang normal dan memiliki debit aliran yang besar dan sesuai. Pada bagian ujung kiri dan kanan pada konstruksi kincir air diikatkan menggunakan kabel seling baja pada tiang pancang yang sudah dipersiapkan di pinggir sungai. Diharapakan ketika air sungai meluap maka kincir tetap akan terapung dan hanya naik sampai batas ketinggian air.

Kinerja kincir air terapung (Gambar 6) untuk mengoptimalisasi penggunaan di masyarakat, maka dilakukan pengukuran sehingga memperoleh informasi diantaranya kecepatan aliran air sungai rata-rata sebesar $0,75 \mathrm{~m} /$ det. Sehingga dengan kecepatan air rata-rata ini dapat menghasilkan putaran sudu kincir sebesar 8,75 Rpm. Putaran yang dihasilkan poros kincir kemudian ditransmisikan ke pompa torak menggunakan perbandingan puli yang hubungkan melalui sabuk menjadi ouput putaran sebesar $22 \mathrm{Rpm}$. Kekuatan aliran air menyebabkan poros berputar, sehingga mendorong keterkaitan (Feiler, 2009). Dari kondisi ini, kapasitas debit 
pompa hanya 3,95 lpm (liter/menit) dengan efisiensinya sebesar 85\%. Diperkirakan dalam 1 hari (24 jam) dapat menggerakkan sudu kincir sehingga kapasitas kerja pompa dapat mensuplai air sebesar 5,68 m³/hari air dapat dipindahkan ke sawah tadah hujan (Gambar 7).

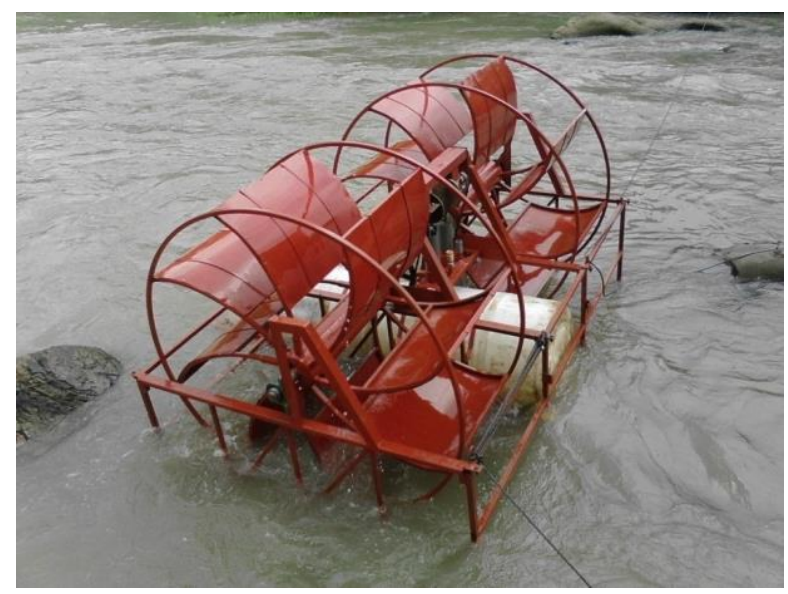

Gambar 6. Kincir Air Terapung yang direkayasa

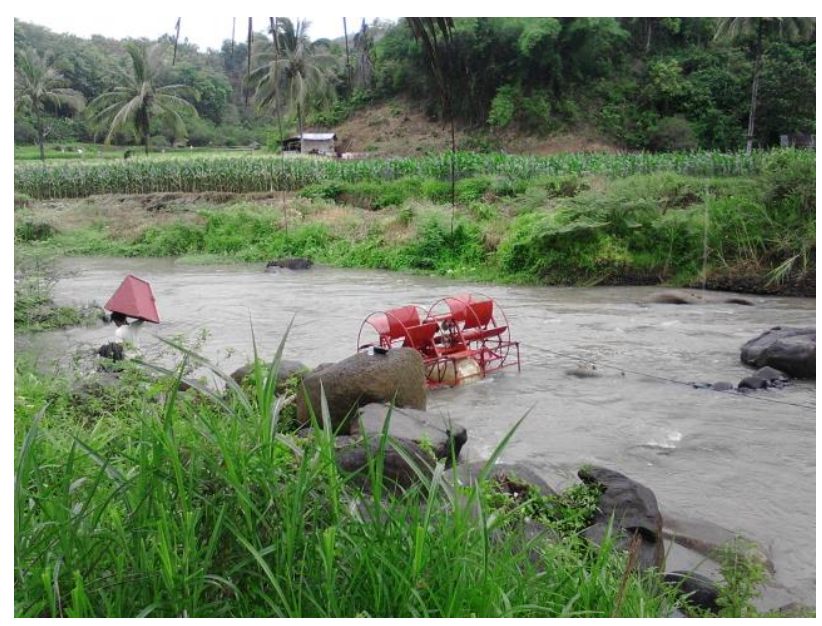

Gambar 7. Penerpan Kincir Air Terapung di sungai

Program kegiatan Ipteks bagi Masyarakat yang dilaksanakan berdampak positif terhadap masyarakat. Ketercapaian kegiatan ini tentunya selesainya kincir air terapung sampai pada kondisi terpasang di lapangan sehingga dapat dipergunakan oleh masyarakat mitra untuk menaikkan air ke sawah mereka yang berada di ketinggian. Hal ini terungkap dari penyampaian masyarakat dan perangkat nagari kepada tim pelaksana. Pandangan tersendiri bagi masyarakat dengan memanfaatkan teknologi yang diterapkan melalui kegiatan IbM. Masyarakat dapat menyelesaikan permasalahan yang terjadi khususnya dalam meningkatkan mengatasi kebutuhan air persawahan. dan pemahamannya melalui informasi yang disampaikan oleh tim pelaksana. Harapan berikutnya beberapa hal yang sudah diterapkan dapat digunakan dan dijaga serta dilaksanakan perawatannya oleh masyarakat dalam meningkatkan produktifitas masyarakat mitra dan Nagari Rajo Dani Padang Ganting. 


\section{KESIMPULAN}

Pelaksanaan kegiatan yang telah dilakukan dalam program Iptek bagi Masyarakat di Kenagarian Rajo Dani Padang Gantiang Tanah Datar didapatkan beberapa kesimpulan daiantaranya yaitu keberhasilan tim pelaksana melakukan rancang bangun kincir air yang dapat diterapkan ke masyarakat mitra pengguna dan sekaligus mengatasi permasalahan masyarakat mitra kegiatan.

Karakteristik kincir air terapung yang telah di laksanakan sebagai rancang bangun memiliki konstruksi berukuran panjang $2 \mathrm{~m}$ dan lebar 2,6 m serta tinggi 0,75 m. Pada bagian bagian tengah kincir diletakkan 3 buah drum palstik sebagai pengapung. Drum palstik yang digunakan berukuran diameter 0,65 m x 0,95 m yang berkapasitas 100 liter. Keseluruhan sistem konstruksi menggunakan penyambungan baut (knok down). Konstruksi dudukan sudu kincir sebanyak 2 buah diposisikan pada bagian samping kiri dan kanan berukuran diameter 1,8 $\mathrm{m}$ dan lebar 0,8 $\mathrm{m}$. Sudu dibuat menggunakan aluminium plat dengan ketebalan $2 \mathrm{~mm}$. Jumlah sudu kincir yang dibuat sebanyak 8 buah sudu. Pada bagian tengah di pasang poros kincir berukuran 2". Poros kincir diselubungi oleh pipa berukuran diameter 6".

Rekayasa pompa torak yang memiliki diameter torak $68 \mathrm{~mm}$, panjang langkah torak 150 mm dan tinggi konstruksi pompa torak $35 \mathrm{~cm}$ dengan 2 buah katup berukuran 1" katup masuk dan katup keluar 3/4" yang diposisikan pada ujung silinder. Kinerja kincir air terapung dengan kecepatan aliran air sungai rata-rata sebesar $0,75 \mathrm{~m} /$ det dapat menghasilkan putaran sudu kincir sebesar 8,75 Rpm. Putaran yang dihasilkan poros kincir kemudian ditransmisikan ke pompa torak menggunakan puli dan sabuk sehingga menjadi ouput putaran sebesar 22 Rpm. Dari kondisi ini, kapasitas debit pompa hanya 3,95 lpm (liter/menit) dengan efisiensinya sebesar 85\%. Diperkirakan dalam 1 hari (24 jam) dapat menghasilkan kapasitas kerja pompa dalam mensuplai air sebesar $5,68 \mathrm{~m}^{3} /$ hari.

\section{DAFTAR PUSTAKA}

Darmawi, D., Sipahutar, R., Bernas, S. M., \& Imanuddin, M. S. 2013. Pico Hydropower Application on Tidal Irrigation CanalSupporting The Indonesian Agricultural Activities Case Study: Telang II-Banyuasin. International Journal on Advanced Science, Engineering and Information Technology, 3(1), 89-92.

Datar, B. T. 2012. Tanah Datar dalam Angka 2011. BPS Dan Bappeda Kabupaten Tanah Datar.

Feiler, F. J. 2009. Floating water turbine for a power plant.

Ismanto, D., Trinofrandesta, E., \& Hamid, H. (2015). Rancang Bangun Kincir Air sebagai Tenaga Penggerak Pompa. Program Kreativitas Mahasiswa-Teknologi.

Namara, R. E., Horowitz, L., Kolavalli, S., Kranjac-Berisavljevic, G., Dawuni, B. N., Barry, B., \& Giordano, M. 2011. Typology of irrigation systems in Ghana (Vol. 142). IWMI.

Nurdin, H., Hasanuddin, H., \& Irzal, I. 2017. Optimalisasi Pemanfaatan Mesin Pompa untuk Mensuplai Kebutuhan Air Sawah Tadah Hujan di Nagari Sumani. 
Suluah Bendang: Jurnal Ilmiah Pengabdian Kepada Masyarakat

Vol19, No.2, 2019

Hendri Nurdin, Hasanuddin, Irzal, Waskito

Streeter, V. L., Wylie, E. B., \& Bedford, K. W. 1985. Fluid mechanics (Vol. 9). McGraw-Hill New York et al.

Sularso, K. S. 2004. Perencanaan dan Pemilihan Elemen Mesin. Cetakan Ke, 11.

Sule, L. 2015. Kinerja Yang Dihasilkan Oleh Kincir Air Arus Bawah Dengan Sudu Berbentuk Mangkok.

Yusri, Y., Zamri, A., \& Asmed, A. 2012. Analisis daya dan putaran kincir air tradisional sebagai alternatif sumber daya penggerak. JURNAL TEKNIK MESIN, 1(2), 82-85. 